\title{
Text Illustrations
}

\section{Maps}

1. General map of Central Asia showing the principal sites on the pre-Islamic trade routes. Prepared by Virginia Herrick. 4

2. Transoxiana showing medieval sites, principal modern cities and present political boundaries. Prepared by Virginia Herrick. I2

\section{Figures}

1. Plan of ancient town of Panjikent showing sectors excavated before I973. 2I

2. Living quarters of Panjikent datable to the eighth century. (I) Entrance eivān, (2) ramp, (3) corridor with painting, (4) main hall, (5) main room of the second story, (6) housekeeping facilities of the second story, (7) shops and workshops, (8) forge, (9) room on the first floor in the home of an ordinary citizen, (12) street. Reconstruction by L.L. Gurevich. 22

3. Main hall of a Panjikent home. At bottom, a mural depicting a goddess and donors. Reconstruction by L.L. Gurevich. 24

4. Excavations of living quarters of Panjikent XXIII and XXIV. Rooms 21, 4, 5 and 24 are narrow streets, covered with arches with second stories above the narrow streets. 25

5. The Sogdian god Veshparkar. Sketch of mural from Panjikent XXII:1. Eighth century. 30

6. Sacrificial altars on a throne. Sketch of mural from the western wall of Panjikent III: 6. Eighth century. 3I

7. Enthroned deities. Sketch of mural from Panjikent XXIV:2. Eighth century. 32 
viii Text Illustrations

8. Enthroned deities. Sketch of mural from Panjikent XXIV:13. Eighth century. 33

9. Deity with the figure of a camel. Terra-cotta from Panjikent. Sixth century. The Hermitage Museum, Leningrad. 34

10. Reconstruction of the early city wall of Panjikent. Period I: fifth century. Period II: ca. 500. Period III: last quarter of seventh century. 38

11. Schematic plans of temples from Panjikent. II: Temple II. I: Temple I. A: Sanctuary of Temple I. B: The north chapel from the precincts of Temple II. Arrangement of the paintings in the north chapel: (I) goddess on the throne with sēnmurvs, (2) donors, (3) goddess on a lion throne (?), (4) donors, (5) goddess on a dragon. 4I

12. Mounted squadrons. Sketch of mural from the northern wall of the portico of the principal hall of Temple II, at Panjikent. Fifth-sixth centuries. 42

13. Four-armed goddess on a dragon. Sketch of mural from the northern chapel of Temple II, at Panjikent. Sixth century. 43

14. Chariot of Veshparkar, harnessed with boars. Sketch of mural from the southern part of the western wall of the portico of the principal hall of Temple I at Panjikent. Sixth century. 44

15. Sketch of mural from the northern wall of Panjikent VI:41-42. Sixth century. 45

16. Hunting scene. Sketch of mural from the southern part of the eastern wall of Panjikent XXIII: 26. Seventh century. 46

17. Preparation for the removal of murals from the principal hall of Panjikent $X X I V . \quad$ SI

18. Plan of Panjikent XXI. Rooms 1-4 were decorated with murals ( $\mathrm{I}$ : principal hall, 2: corridor, 4: room with hearth-altar). Rooms 7-8: halls without paintings. Room 19: eivān. Rooms 13, 22, 23: workshops. 52

19. Plan of Panjikent XXIV. Rooms 1-4, 6, 9, 10 are included in one dwelling ( 1 : hall, 2-3: corridor, 4: eivān). The murals were situated in Rooms 1-4, on the second story above the eivän, and above Room 10. 53

20. Vase. Sketch of a detail of mural from the eivan, Panjikent XXIV. Eighth century. 54 
21. Person with dish and vase. Sketch of mural from the eivān (Room 4) of Panjikent XXIV. Eighth century. 55

22. Human-headed birds. Sketch of mural from cornice of eivān (Room 4) of Panjikent XXIV. Eighth century. S5

23. Donors. Sketch of mural from the eastern wall of the northern chapel of Temple II, at Panjikent. End of the fifth century. 56

24. Fragment of the same painting as in fig. 23 , in the process of restoration. 57

25. Sketch of mural from the southern wall of the portico of the main building of Temple I, at Panjikent. Sixth century. 58

26. Musicians. Sketch of mural from the cornice of Panjikent VI:42. Eighth century. 60

27. Kneeling figures on the side wall of a niche containing a representation of Veshparkar. Sketch of mural from Panjikent XXII:1. Eighth century. 64

28. Manjaniq siege machine. Sketch of a fragment of a mural from the palace at Panjikent. First quarter of the eighth century. 65

29. Photograph of the same fragment as in fig. 28. 65

30. Diadem with wings and crescent being fastened around ruler's helmet. Fragment of a mural from the palace at Panjikent. First quarter of the eighth century (in the process of restoration). 66

31. Fragments of murals from the palace at Panjikent. From left to right: an Arab, winged camel, head of a youth. First quarter of the eighth century. 66

32. Sketch of fragments of a mural depicting a battle of gods and men against dêws: Nanā is on the lion facing the chariot of the sun as it rushes toward her. Eastern wall of Panjikent III:6. Eighth century. 68

33. Dahḥāk. Sketch of mural from the northwestern corner of the portico of the principal hall of Temple I, at Panjikent. Sixth century. 69

34. Goddess on a throne supported by sēnmurvs. Sketch of mural from the eastern wall of the northern chapel of Temple II, at Panjikent. End of the fifth century. 7I

35. God on a throne supported on horses. Sketch of mural from the north wall of Panjikent XXVI:1. Eighth century. 72 
36. Sketch of a detail of a mural from Panjikent XVI:10. Eighth century. 74

37. Lower ornamental border. A reconstruction of a mural from the west wall of the portico of Panjikent X. Seventh-eighth centuries. 75

38. Bodhisattva painted in the niche to the left of the Great Buddha, Bāmiyān, Afghanistan. Photo courtesy Josephine Powell. 85

39. Female donor painted on the vault to the right of the Great Buddha, Bāmiyān, Afghanistan. Photo courtesy Josephine Powell. 86

40. Banqueters depicted in the mural on the west wall of the principal hall at Balalyk-tepe, Uzbekistan SSR. Sixth-seventh centuries. Sketch after Al'baum, Balalyk-tepe, fig. I05. 88

41. Early Sasanian mural from Ghāgha-shahr IV, Kūh-i-Khwāja, Sistan, showing two male figures. Central Asian Antiquities Museum, New Delhi, height 5 feet, width 7.3 feet. Copy after Stein, Innermost Asia III, pl. 54. 90

42. Sogdian mural depicting episodes from the "Rustam cycle," north wall of Panjikent VI: 41, The Hermitage Museum, Leningrad. Photo courtesy Josephine Powell. 96

43. Sogdian mural depicting episodes from the "Rustam cycle," west and north walls, Panjikent VI:41. Sketch after Belenitskii, in Materialy vtorogo soveshchaniia arkheologov i ètnografov Srednei Azii, Akademiia Nauk SSSR, Institut ètnografii im. N.N. Miklukho-Maklaia, Moskva/Leningrad 1959, fig. 4. 97

44. Sogdian mural depicting episodes from the "Rustam cycle," north wall, Panjikent VI: 41. Sketch after Belenitskii, in KSIIMK 73, 1959, fig. 35. 98

45. Sogdian mural depicting a warrior in heavy armor engaged in single combat, from Panjikent VI: 55. Sketch after Belenitski, Marshak, in Arts Asiatiques XXIII, I97I, fig. II. 106

46. Sogdian mural depicting a female warrior engaged in single combat, from Panjikent VI: 55. Sketch after Belenitski, Marshak, in Arts Asiatiques XXIII, 1971, fig. I2. 107

47. Detail of a battle scene from a Sogdian mural from Panjikent XXIV. Sketch after Belenitskii, Marshak, in SGE XXXVI, 1973, 63. I Io

48. Scenes of sacrifice at a fire altar and banquet from a Sogdian mural from Panjikent I:10. Sketch after Zhivopis', pl. VII. II I 
49. God with a rayed halo and torch depicted in the mourning scene, in the Sogdian mural from the tetrastyle hall of Temple II, at Panjikent, Panjikent II:V. Copy after Zhivopis', pl. XXIII (see figs. 56, 57). II3

50. Female participants in a procession of Chaghanian emissaries to the Sogdian royal court at Samarkand. Samarkand, Room 1. Reconstructed sketch after Al'baum, Zhivopis' Afrasiaba, fig. Iо. II 8

51. Detail of a Sogdian mural from the west wall of Room 1, at Samarkand. Inscription identifies the figure with cap as Vargoman, ruler of Samarkand, mid seventh century. Copy. II

52. Representation of a delegation of Turks among the foreign missions at the Sogdian court at Samarkand. Sogdian mural from the west wall of Room 1, Samarkand. Reconstructed sketch after Al'baum, Zhivopis' Afrasiaba, fig. 7. I20

53. Detail of a Sogdian mural depicting a royal banquet, from Panjikent VI:1. Sketch after Zhivopis', pl. XXXVI. I2I

54a. Sogdian mural depicting the tale of the slaughter of the goose that laid golden eggs, from Panjikent XXI:1. Sketch after Belenitski, Marshak, in Arts Asiatiques XXIII, 1971, fig. 14. 122

54b. Sogdian mural depicting the tale of the clever hare and the lion, from Panjikent XXI:1. Sketch after Belenitski, Marshak, in Arts Asiatiques XXIII, I97I, fig. Is. I23

55. Representation of an unknown fable in a Sogdian mural from Panjikent VI: 41. Sketch after Belenitskii, in Arkheologicheskie raboty $v$ Tadzhikistane $v 1956$ godu, fig. Is. 124

56. Sogdian mural depicting a scene of mourning from the south wall of the tetrastyle hall of Temple II, Panjikent. Sketch after Zhivopis', pl. XIX (see figs. 49, 57). $\quad 127$

57. The heads of the deceased and a mourner, from a detail of the mourning scene, from the south wall of the tetrastyle hall of Temple II, Panjikent. Copy after Zhivopis', pl. XXI (see figs. 49, 56). $\quad 128$

58. A four-armed goddess depicted in a Sogdian mural from the south wall of a vaulted room from Panjikent VI:26. Sketch after Belenitskii, Monumental'noe iskusstvo Pendzhikenta, 26. 133 
xii Text Illustrations

59. A Sogdian version of the Romulus and Remus legend, depicted in a mural from Room 1, Qal'a-i Qahqaha I, Ustrushana. Sketch after Negmatov, in $S A 3$, I973, fig. I5. $\quad 142$

60. An unknown Sogdian epic depicted in a Sogdian mural from Panjikent XXII:1. Sketch after Belenitskii, Monumental'noe iskusstvo Pendzhikenta, 33. 146

61. A royal hunt depicted on a Sogdian silver vessel of the early Muslim period, in the Hermitage Museum, Leningrad. Sketch after Marshak, Sogdiiskoe serebro, pl. 30. $\quad 172$

62. Manichaean angels from a detail of a Turfanese scroll with a Sogdian text, datable to A.D. ninth-tenth century. Museum für indische Kunst, the State Museum, Berlin. Ca. $22 \times 2 \mathrm{I} \mathrm{cm} . \quad \mathrm{I} 73$

63. Turfanese mural depicting a Tantric goddess, ca. A.D. ninth century. The Central Asian Antiquities Museum, New Delhi. Photo courtesy Josephine Powell. I74

64. Male figure painted on a pillar from the Ghaznavid palace at Lashkari Bāzār, Afghanistan, datable to A.D. eleventh century. The Archaeological Museum, Kabul. Height of head ca. $18 \mathrm{~cm}$. Photo courtesy Josephine Powell. ${ }_{176}$ 